\title{
Performance Evaluation of Nitrogen Removal Type On-site Treatment System for Domestic Wastewater
}

\author{
YOKO FUJIMURA ${ }^{1}, \mathrm{KOICHI} \mathrm{KIUCH}^{2}$, YOSHIMASA AMANO ${ }^{1,3}$, and MOTOI MACHIDA ${ }^{1,3}$ \\ ${ }^{1}$ Graduate School of Engineering, Chiba University/1-33, Yayoi-cho, Inage-ku, Chiba 263-8522, Japan \\ ${ }^{2}$ Chiba Prefectural Environmental Research Center \\ /3-5-1, Inage-kaigan, Mihama-ku, Chiba 261-0005, Japan \\ ${ }^{3}$ Safety and Health Organization, Chiba University/1-33, Yayoi-cho, Inage-ku, Chiba 263-8522, Japan
}

\begin{abstract}
In this study, the performance of on-site treatment system for domestic wastewater (Johkasou) was evaluated. The qualities of effluent from actual nitrogen removal type Johkasou which has begun to become popular recently and removal efficiencies were examined. The nitrogen removal type Johkasou showed better performance for BOD and nitrogen removal than the conventional type Johkasou. Both BOD and total nitrogen $(\mathrm{T}-\mathrm{N})$ concentrations were $15 \mathrm{mg} / \mathrm{L}$ or less in $75-80 \%$ of effluent water samples investigated. The high performance of the treatments system was attributed to a mixed liquor recycle system for denitrification. The reduction of BOD concentration in the effluent water was also observed accompanied by the high efficiency of nitrogen removal. Recycling of treated water would result in improving reduction of not only $\mathrm{NO}_{3}-\mathrm{N}$ but also dissolved Kjeldahl nitrogen (DKN) reduction, and the decrease in DKN led to a decrease in both N-BOD and BOD as well. The denitrification activity was declined when circulation ratio drop to $1 \mathrm{Q}$ or less where $Q$ is the influent flow quantity. The effluent $T-N$ seemed to be controlled below $20 \mathrm{mg} / \mathrm{L}$ with the recycle ratio of $2 \mathrm{Q}-15 \mathrm{Q}$. The average removal rates of $\mathrm{T}-\mathrm{N}$ and total phosphorus (T-P) of the surveyed Johkasous were $67 \%$ and $58 \%$, respectively.
\end{abstract}

Key words: Domestic wastewater, on-site treatment, nitrogen removal type Johkasou, N-BOD

\section{INTRODUCTION}

In Japan a large number of individual houses are using on-site treatment system for domestic wastewater in the areas not provided with a public sewerage system ${ }^{1-4)}$. The on-site treatment systems are designed, constructed, operated and maintained systematically according to the laws controlled by the Ministry of Construction and the Ministry of Health and Welfare, as well as collection and treatment of their sludge. They are called Johkasou which plays an important role to reduce water pollution caused by domestic wastewater in Japan. Johkasou consists of a pretreatment process (anaerobic filter tank) followed by an aerobic process (contact aeration tank). The smallest type of the Johkasou for 5-10 population equivalents (p.e.) contains an aerobic process, which is distinctly different from septic tanks, and the BOD of the effluent after treatments of these systems is expected to be less than $20 \mathrm{mg} / \mathrm{L}$ in most of the cases ${ }^{1)}$. Johkasou is a way to effectively treat domestic wastewater before it flows into the drainage of the residential area. However, the effluent from Johkasou has still been reported as one source of pollution in coastal areas such as lakes and bays $^{5), 6)}$. 
Recently, Johkasou having the functions of removing nitrogen and phosphorus has been developed ${ }^{7,8)}$. The Johkasou that can remove nitrogen or phosphorus is called "advanced treatment type". Nitrogen removal type Johkasou is widely used in Japan ${ }^{5), 9)}$, although phosphorus removal type one is not widespread because of high capital and operation costs. The nitrogen removal type Johkasou is equipped with an apparatus that circulates treated water to a conventional general system having an anaerobic tank and a contact aeration tank.

A typical scheme of nitrogen removal type Johkasou is represented in Fig. 1. The plastic filter media were installed in the anaerobic filter tank and the contact aeration tank, and the treated water was returned to anaerobic tank for circulation. There are three levels for the nitrogen removal type Johkasou due to the limitation of BOD and $\mathrm{T}-\mathrm{N}$ concentrations in the final effluent. They are classified into 1) $20 \mathrm{mg}-\mathrm{BOD} / \mathrm{L}$ and $20 \mathrm{mg}-$ $\mathrm{T}-\mathrm{N} / \mathrm{L}$, 2) $10 \mathrm{mg}-\mathrm{BOD} / \mathrm{L}$ and $20 \mathrm{mg}-\mathrm{T}-\mathrm{N} / \mathrm{L}$, and 3) $10 \mathrm{mg}-\mathrm{BOD} / \mathrm{L}$ and $10 \mathrm{mg}-\mathrm{T}-\mathrm{N} / \mathrm{L}^{4)}$. The structure of nitrogen removal type Johkasou has an ability to reduce BOD and $\mathrm{T}-\mathrm{N}$ concentrations to less than the above three combinations for the discharge effluent. The research area of this study (Sakura City, Japan) is the watershed of Lake Inba-numa and removal of nutrients from domestic wastewater is required in this area. In this research area most of the nitrogen removal type Johkasous were $20 \mathrm{mg}-\mathrm{BOD} / \mathrm{L}$ and 20 $\mathrm{mg}-\mathrm{T}-\mathrm{N} / \mathrm{L}$ type.



Fig. 1 Typical scheme of small-scale nitrogen removal type Johkasou; individual household type.
When using advanced treatment type Johkasou as a water purification countermeasure for lakes and bays, in order to ascertain the pollution load to the watershed from the Johkasous it is necessary to clarify the actual water quality of effluent from the Johkasou and to determine the pollutant load factor. In spite of the nitrogen removal type Johkasou ever being widely provided in Japan, the performance of treatment in a large number of actual facilities has not been reported yet, including problems and improvements on them. This paper reports small-scale nitrogen removal type Johkasou concerning their good performance of nitrogen removal and decline of BOD by utilizing the circulation system.

\section{METHODS}

Outline of the examined nitrogen removal type Johkasous Thirty-four nitrogen removal type Johkasous smaller than 10 p.e. in Sakura City (Chiba Prefecture) were surveyed from 1998 to 2004. From 1998 to 1999, each of seven facilities was examined once to six times, and from 2000 to 2004, duplicate investigations were conducted for each of twenty-seven facilities. In all facilities the mixed liquor in contact aeration tank was continuously recycled into the anaerobic filter tank using the air lift pump for removing nitrogen and carrying biofilm that sloughed off by backwashing. Recycling of mixed liquor is sustained with the aid of the maintenance by expert engineers three times a year for checking and confirming the normal operation of the equipment.

Sample collection and water analysis The effluent was sampled in the sedimentation tank just before disinfection in each facility, then temperature, transparency, and $\mathrm{pH}$ (HPH-110 pH meter, DKK Co., Ltd.) of the effluent were measured at each site. Dissolved oxygen (DO) (UC-12 DO meter, CENTRAL KAGAKU Co., Ltd.) in the contact aeration tank and the amount of mixed liquor recycled were measured as well. Samples were immediately transferred to laboratory and stored at below $10^{\circ} \mathrm{C}$ before use. Biochemical oxygen demand (BOD), BOD with addition of $\mathrm{N}$-allylthiourea to inhibit nitrification (ATUBOD), and chemical oxygen demand using 
$\mathrm{KMnO}_{4}$ at $100^{\circ} \mathrm{C}\left(\mathrm{COD}_{\mathrm{Mn}}\right)$ were quantified according to titration methods. The effluent for the measurement of suspended solids (SS) was filtrated by glass fiber filter (GS-25, ADVANTEC TOYO Co., Ltd.), then the filter was warmed at $110^{\circ} \mathrm{C}$. And then, the sample was allowed to be cooled in desiccator and weighed. Nutrient concentrations in the effluent were also measured. Total nitrogen $(\mathrm{T}-\mathrm{N})$ and dissolved total nitrogen (DTN) were measured by a total nitrogen analyzer (TN-05, Mitsubishikasei Co., Ltd.). Particulate total nitrogen (PTN) was calculated by subtracting DTN from T-N. Total phosphorus (T-P) concentration was obtained based on molybdenum blue method. Nitritenitrogen $\left(\mathrm{NO}_{2}-\mathrm{N}\right)$ and nitrate-nitrogen $\left(\mathrm{NO}_{3}\right.$ -N) concentrations were measured by ion chromatograph (DX120, DIONEX Co., Ltd.) after filtrating the sample using a $5-\mathrm{mL}$ syringe with PTFE syringe filter. Nitrification BOD (N-BOD) and dissolved Kjeldahl nitrogen (DKN) were calculated by subtracting ATU-BOD from BOD and subtracting $\mathrm{NO}_{2}-\mathrm{N}+\mathrm{NO}_{3}-\mathrm{N}$ from DTN, respectively. Each measurement was conducted in accordance with JIS (Japan Industrial Standard) K $0102(1998)^{10)}$.

\section{RESULTS AND DISCUSSION}

\section{Effluent water qualities of nitrogen removal} type Johkasous The frequency distributions of the effluent BOD and T-N concentrations in the surveyed nitrogen removal type Johkasous which treated individual household wastewater are shown in Fig. 2. The frequency was highest in the class of less than $5 \mathrm{mg} / \mathrm{L}$ and $5-10 \mathrm{mg} / \mathrm{L}$ for BOD and $\mathrm{T}-\mathrm{N}$, respectively, in the effluent water. Approximately $80 \%$ of BOD and $75 \%$ of $\mathrm{T}-\mathrm{N}$ data for the final effluent water exhibit below $15 \mathrm{mg} / \mathrm{L}$.

In the nitrogen removal type Johkasou, it was easy to regulate the amount of the recycled liquor by controlling the airlift pumps at the recycle ratio of $3 \mathrm{Q}-4 \mathrm{Q}$ where $\mathrm{Q}$ was the influent flow quantity. Therefore, the mixed liquor in the contact aeration tank was recycled to the anaerobic filter tank at most of the facilities with an appropriate recycle rate. In the conventional Johkasou, the recycling ratio was not stabilized because the control system for recycling mixed liquor was not equipped ${ }^{11)}$.

The data ranges for the effluent water qualities and their average values are shown in Table 1. The results were presented for nitrogen removal type Johkasou compared with conventional type without recycling ${ }^{1}$. In conventional type Johkasou the water with biofilm in the sedimentation tank can be circulated to the anaerobic filter tank by manual operation, but it cannot be circulated continuously ${ }^{11}$. It was obvious that the values of BOD, N-BOD, T-N, and DKN in effluent water for the nitrogen removal type Johkasou were lower than those of conventional Johkasou. The significant decrease in $\mathrm{T}-\mathrm{N}$ suggested that the denitrification of $\mathrm{NO}_{3}-\mathrm{N}$ could take place in the anaerobic filter tanks by recycling liquor containing $\mathrm{NO}_{3}-\mathrm{N}$. The organic matter in the influent could be used for the denitrification. The mechanism to remove nitrogen in nitrogen removal type
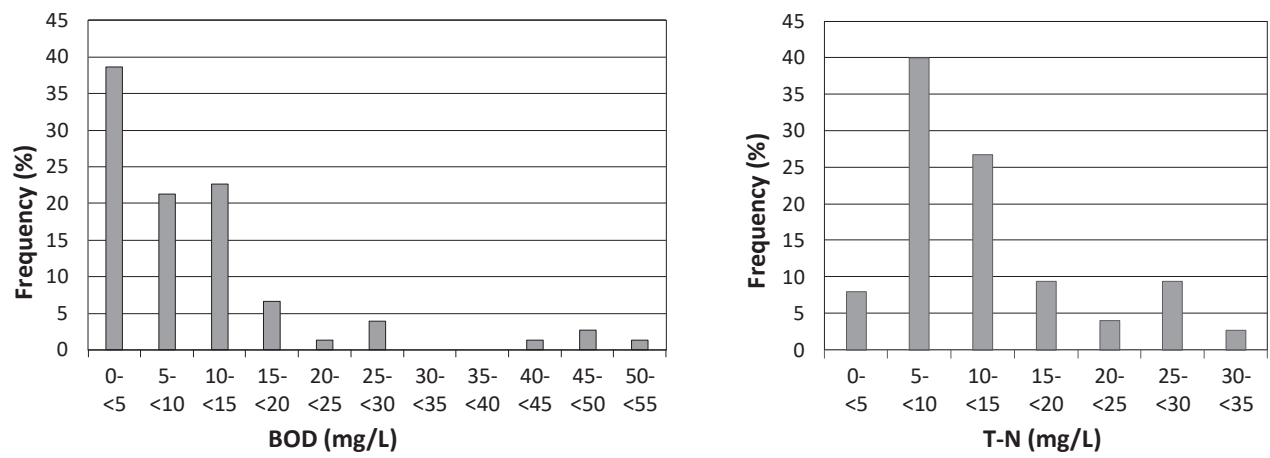

Fig. 2 Distributions of the effluent BOD and $\mathrm{T}-\mathrm{N}$ in the nitrogen removal type Johkasous. Sample number of BOD: $75, \mathrm{~T}-\mathrm{N}$ : 75 
Table 1 Effluent water qualities in the nitrogen removal type Johkasou and conventional Johkasou

\begin{tabular}{|c|c|c|c|c|}
\hline & \multicolumn{2}{|c|}{$\begin{array}{l}\text { Nitrogen removal } \\
\text { type Johkasou } \\
\qquad \mathrm{n}=75\end{array}$} & \multicolumn{2}{|c|}{$\begin{array}{c}\text { Conventional } \\
\text { Johkasou without } \\
\text { treated water recycle } \\
\mathrm{n}=68\end{array}$} \\
\hline & $\min -\max$ & average & $\min -\max$ & average \\
\hline BOD & $0.9-55$ & 10 & $2.3-127$ & 19 \\
\hline ATU-BOD & $0.6-48$ & 5.9 & $1.2-41$ & 7.3 \\
\hline N-BOD & $0-50$ & 4.5 & $0-86$ & 12 \\
\hline CODMn & $6.0-38$ & 14 & $7.1-47$ & 17 \\
\hline SS & $1-59$ & 8.4 & $0.5-63$ & 13 \\
\hline $\mathrm{T}-\mathrm{N}$ & $4.0-33$ & 12 & $7.1-74$ & 25 \\
\hline $\mathrm{NO}_{3}-\mathrm{N}$ & $0.2-29$ & 6.2 & $0.03-56$ & 14 \\
\hline DKN & $0-31$ & 4.8 & $0-37$ & 9.2 \\
\hline $\mathrm{T}-\mathrm{P}$ & $0.7-8.5$ & 2.9 & $0.31-7.6$ & 3.1 \\
\hline
\end{tabular}

Johkasou was effective even at the actual facilities.

Decline of BOD in effluent water from nitrogen removal type Johkasous In the nitrogen removal type Johkasou, BOD in effluent water also remarkably decreased compared with the conventional Johkasou (Table 1). Fig. 3 shows the relationship between $\mathrm{T}-\mathrm{N}$ and BOD in the effluent of nitrogen removal type Johkasou. As shown in Fig. 3, the majority of data plots for BOD and $\mathrm{T}-\mathrm{N}$ were less than $15 \mathrm{mg} / \mathrm{L}$. However, when BOD values exhibited above $15 \mathrm{mg} / \mathrm{L}$, the $\mathrm{T}-\mathrm{N}$ values were somewhat proportional to the BOD values, suggesting that reduction of nitrogen could contribute to BOD removal in the nitrogen removal type Johkasou.

BOD consists of ATU-BOD and N-BOD. $\mathrm{N}-\mathrm{BOD}$ is a BOD produced when ammonia nitrogen consumes oxygen in the presence of nitrifying bacteria in wastewater ${ }^{12)}$. It is often observed at high concentration in treated water in Johkasou ${ }^{11}$. N-BOD in treated domestic wastewater may also affect quality of river water into which wastewater is discharged ${ }^{13), 14)}$.

As shown in Fig. 4, ATU-BOD and NBOD in effluent from the nitrogen removal type Johkasou occupied about half of BOD, respectively. On the other hand, in conventional type Johkasou, the higher the concentration of $\mathrm{BOD}$, the larger the proportion of $\mathrm{N}-\mathrm{BOD}$ than $\mathrm{ATU}-\mathrm{BOD}^{11)}$. It

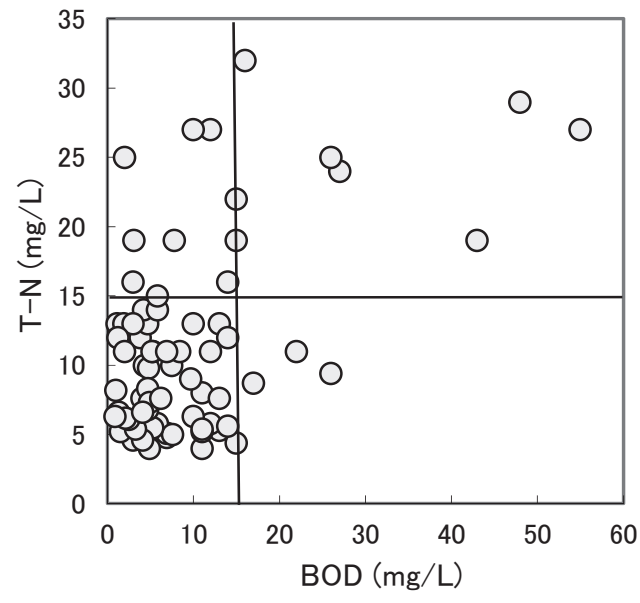

Fig. 3 Relationship between the effluent BOD and T-N in the nitrogen removal type Johkasous. Sample number of data: 72

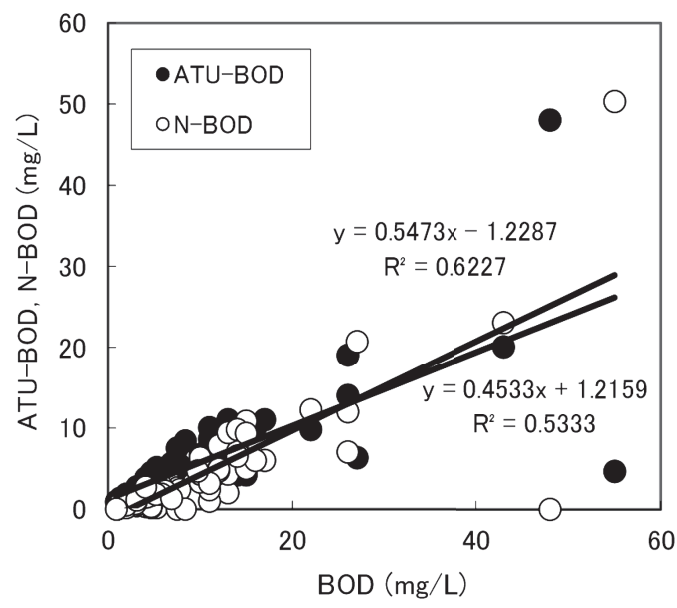

Fig. 4 Relationship between the effluent BOD and ATU-BOD and N-BOD in the nitrogen removal type Johkasous.

Sample number of data: 72

could be suggested that the BOD of effluent in the nitrogen removal type Johkasou was lower than the BOD of the conventional type Johkasou because the N-BOD of the nitrogen removal type Johkasou was low.

In this survey, DTN occupied most of the $\mathrm{T}-\mathrm{N}$ of the effluent water (Fig. 5). DTN is generally composed of $\mathrm{NO}_{3}-\mathrm{N}, \mathrm{NO}_{2}-\mathrm{N}$, and DKN. DKN in nitrogen removal type Johkasou was approximately half of that in conventional Johkasou (Table 1). As shown in Fig. 6, $\mathrm{NO}_{3}-\mathrm{N}$ occupied a large part of DTN 
in effluent water at low concentration, and the DKN portion was very low in contrast. DKN consists of organic nitrogen and ammonia nitrogen. Based on our findings and treated water qualities in biological treatment of sewage water ${ }^{15,16)}$, it was inferred that more than $80 \%$ of the DKN of treated water in Johkasou investigated would be $\mathrm{NH}_{4}-\mathrm{N}$. The presence of ammonia nitrogen and nitrifying bacteria produces $\mathrm{N}-\mathrm{BOD}^{12)}$. Therefore, it is inferred that $\mathrm{N}-\mathrm{BOD}$ is decreased due to the decrease of $\mathrm{NH}_{4}-\mathrm{N}$. In

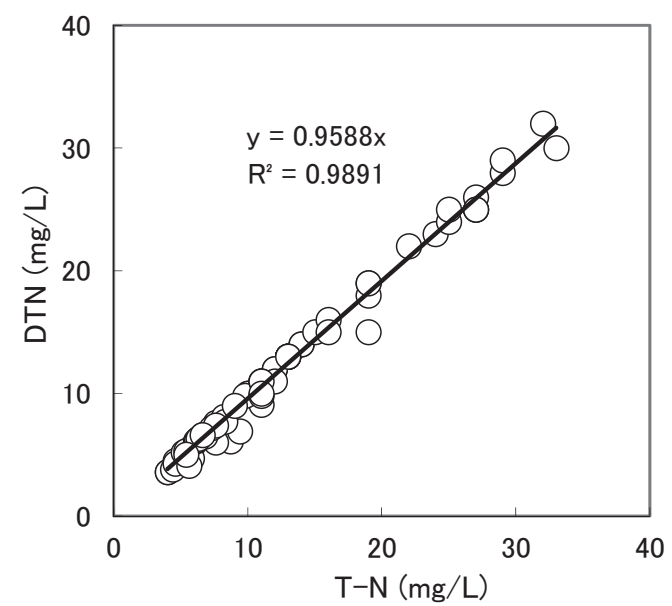

Fig. 5 Relationship between the effluent T-N and DTN in the nitrogen removal type Johkasous. Sample number of data: 75

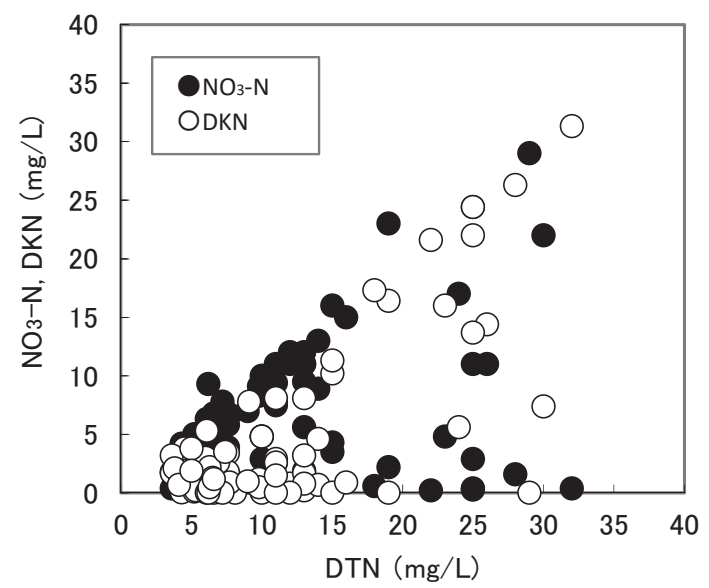

Fig. 6 Relationship between the effluent DTN and $\mathrm{NO}_{3}-\mathrm{N}$ and $\mathrm{DKN}$ in the nitrogen removal type Johkasous.

Sample number of data: 75 the nitrogen removal type Johkasou, the nitrification rate increases and DKN decreases under sufficient aeration. The decrease in DKN resulted in reductions of N-BOD and BOD as well. In a Johkasou where C-BOD (same as ATU-BOD) accounts for the majority of BOD in treated water, the decrease in N-BOD does not affect $\mathrm{BOD}^{17)}$, thereby recycling of treated water may not lead to a decrease in BOD. It is assumed that not only removal of organic matter but nitrogen removal can contribute to BOD removal in nitrogen removal type Johkasou investigated in the present study.

The relationship between the recycle ratio and $\mathbf{T}-\mathbf{N}$ in the effluent water In the process of removing nitrogen from wastewater, the recycling rate of nitrifying solution affects a great influence on the process ${ }^{18)}$. In the nitrogen removal type Johkasou, the recycling rate is adjusted between $3 \mathrm{Q}$ and $4 \mathrm{Q}$ three times a year but in fact it often fluctuates. This is because pipes for recycling and weirs for adjusting the recycling amount tend to be plugged due to the growth of microorganisms in 3 to 4 months. Clogging of the weir for adjusting the recycling amount may also cause an increase in the recycling ratio. The relationship between the recycle ratio and $\mathrm{T}-\mathrm{N}$ in the effluent is shown in Fig. 7. The number of samples exhibiting high $\mathrm{T}-\mathrm{N}$ concentration was increased with the recycle

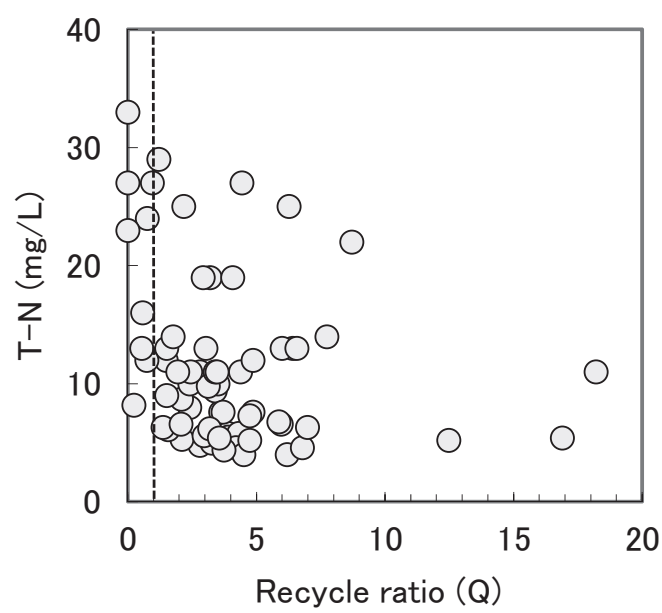

Fig. 7 Relationship between the recycle ratio and the effluent $\mathrm{T}-\mathrm{N}$ in the nitrogen removal type Johkasous. 
ratio of around $1 \mathrm{Q}$ or less. The effluent $\mathrm{T}-\mathrm{N}$ seemed to be largely controlled below 20 $\mathrm{mg} / \mathrm{L}$ with the recycle ratio of $2 \mathrm{Q}$ or more. In this survey, the $\mathrm{T}-\mathrm{N}$ in the effluent was low even if the circulation ratio was $15 \mathrm{Q}$ or more, but this is not always the case. According to the previous surveyed results ${ }^{1)}$, the $\mathrm{T}-\mathrm{N}$ in the outflow water increased when the recycling rate reached $15 \mathrm{Q}$ or more. If the recycle ratio is too high, oxygen is brought into the anaerobic filter tank and denitrification will be inhibited. It does not seem to be preferable that the recycling rate becomes $15 \mathrm{Q}$ or more for nitrogen removal. Maintaining the normal recycling rate is a key point to keep clean effluent from on-site nitrogen removal type Johkasou.

Nitrogen and phosphorus removal efficiency in effluent water In the survey from 2003 to 2004 , we sampled the water for 28 times in total at the first chamber of the anaerobic filter tank (raw water) in addition to the effluent water at 14 Johkasous. The samples were taken between the floating scum and sediment in the first chamber. Fig. 8 shows the average values of nitrogen and phosphorus concentrations of 28 samples for raw water and effluent water.

The average concentrations of T-N, DKN and T-P in the raw water were $39 \mathrm{mg} / \mathrm{L}, 13$ $\mathrm{mg} / \mathrm{L}$ and $6.5 \mathrm{mg} / \mathrm{L}$, respectively, and these concentrations were declined by $67 \%, 70 \%$ and $58 \%$ in the nitrogen removal type Johkasou. As shown in Table 1, T-N and DKN of effluent water in conventional type Johkasou do not seem to be removed so much. The removal rate for T-N and DKN was higher than that of conventional type
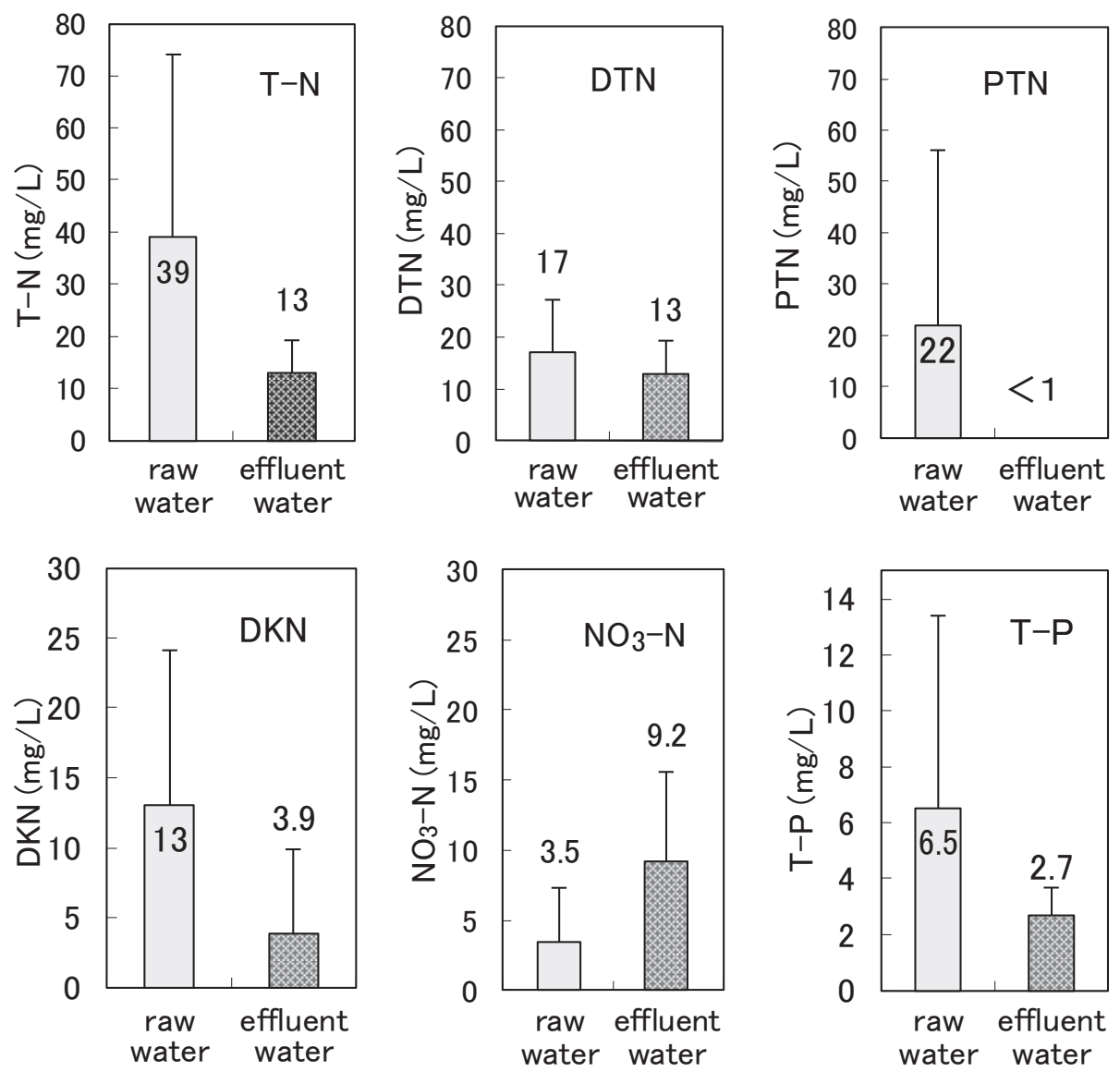

Fig. 8 The average of T-N, DTN, PTN, DKN, $\mathrm{NO}_{3}-\mathrm{N}$, and T-P of 28 samples of raw water and effluent water. Data values are the means of 28 samples, and error bars indicate the standard deviations. 
Johkasou, whereas T-P was not changed considerably (Table 1), because the nitrogen removal type Johkasou does not have any function to remove phosphorus. In coastal areas, it is desirable to use a Johkasou with phosphorus removal function in addition to nitrogen removal functionality.

\section{CONCLUSIONS}

Nitrogen removal type Johkasou showed good performance for BOD and T-N removal with their effluent BOD and T-N below 15 $\mathrm{mg} / \mathrm{L}$, which accounted for $75-80 \%$ of the surveyed data. BOD, N-BOD, T-N and DKN values of the final effluent treated with the nitrogen removal type Johkasou were indeed lower than those of conventional Johkasou. It was suggested that the denitrification occurred in the anaerobic filter tanks, which was attributed to the reduced $\mathrm{NO}_{3}-\mathrm{N}$ in the recycle liquor by utilizing organic substances in the influent. It was also estimated that recycling of treated water led to not only decreases of $\mathrm{NO}_{3}-\mathrm{N}$ but also decreases of DKN that contributed to decreases of both $\mathrm{N}-\mathrm{BOD}$ and BOD. The effluent $\mathrm{T}-\mathrm{N}$ seemed to be controlled below $20 \mathrm{mg} / \mathrm{L}$ in most cases with the recycle ratio of $2 \mathrm{Q}-15 \mathrm{Q}$. The removal rate for $\mathrm{T}-\mathrm{N}$ and $\mathrm{DKN}$ from raw water was higher than that of conventional type Johkasou, whereas T-P was not changed considerably.

\section{ACNOWLEDGEMENTS}

The authors thank the Sakura City Living Environment Section for their co-operation

\section{REFERENCES}

1 ) Nakajima, J., Fujimura, Y., Inamori, Y.: Performance evaluation of on-site treatment facilities for wastewater from households, hotels and restaurants, Water Sci. Technol., 39, 85-92 (1999)

2 ) Gaulke, L. S.: On-site wastewater treatment and reuses in Japan, Proc. ICE-Water Manage. 159, 103-109 (2006)

3 ) JECES: Johkasou database. Japan Education Center of Environmental Sanitation, Tokyo, Japan. http://www.jeces.or.jp/en/database/ index.html (2009) (accessed on January 6, 2017).
4 ) Tsuzuki, Y.: Pollutant discharge and water quality in urbanisation. Springer Science \& Business Media, 61-65, Cham Heidelberg New York London (2014)

5 ) Tanaka, T., Ogiwara, T., Kobayashi, Y., Kinoshita, E., Sugiyama, H.: Pollutant load discharged from johkasou system and its impact on water quality of river and lake, J. Jpn. Soc. Water Environ., 30, 219-225 (2007) (in Japanese)

6 ) Fajri, A. J., Yamada, T., Setiyawan, A. S., Li, F.: Evaluation of water and sediment quality in open channels that receive effluent from Johkasou facilities, J. Water Environ. Technol., 13, 207-219 (2015)

7 ) Imura, M., Sato, Y., Inamori, Y., Sudo, R.: Development of a high-efficiency household biofilm reactor, Water Sci. Tech., 31, 163 $-171(1995)$

8 ) Moriizumi, M., Fukumoto, A., Yamamoto, Y., Okumura, S.: Basic studies on the characteristics of phosphorus removal by the electrochemical elution of iron, J. Jpn. Soc. Water Environ., 22, 459-464 (1999) (in Japanese)

9 ) Takahashi, N., Sasaki, A., Shirakawa, Y., Nomura, M., Nishimura, O.: Comparison for removal of coliform group between BOD removal type Johkasou and nitrogen removal type Johkasou, Jpn. J. Wat. Treat. Biol., 53, 1-10 (2017) (in Japanese)

10) Japanese Standards Association: Testing methods for industrial waste water, JIS K 0102 1998, Japanese Standards Association, Tokyo, Japan (1998) (in Japanese)

11) Fujimura, Y., Nakajima, J.: Effluent water quality of small-scale on-site treatment facilities for household wastewater and nitrogen removal performance with recycle operation, J. Jpn. Soc. Water Environ., 21, 157-162 (1998) (in Japanese)

12) Yamada, K., Ito, Y., Kano, N., Sasaki, H., Sudo, R.: Effect of secondary effluent on nitrogenous BOD (N-BOD) in the rivers, J. Jpn. Soc. Water Environ., 20, 311-317 (1997) (in Japanese)

13) Watanabe, T., Furukawa, Y., Yahashi, T., Ohmori, H., Kitao, T.: Investigation of BOD measurement for estimating the performance of Johkasou system, J. Jpn. Soc. Water Environ., 21, 583-588 (1998) (in Japanese) 
14) Nohara, A., Uchiyama, Y., Nakashima, N.: Nitrogenous BOD evaluation model for river quality model, Environ. Eng. Res., 40, 507-513 (2003) (in Japanese)

15) Waki, M., Yasuda, T., Fukumoto, Y., Kuroda, K., Sakai, T., Suzuki, N., Suzuki, R., Matsuba, K., Suzuki, K.: Nitrogen concentrations of activated sludge process effluent of swine wastewater, J. Jpn. Soc. Water Environ., 33, 33-39 (2010) (in Japanese)

16) Kojima, H., Fujimura, Y.: Investigation of wastewater from convenience store, FY 2008 Annual report of Chiba prefectural environmental research center, Chiba prefecture, Japan. https://www.pref.chiba.lg. jp/wit/suishitsu/report/index.html (2009) (accessed August 25, 2017).
17) Ishiguro, Y., Trianda, Y., Fujisawa, T., Yasufuku, K., Okumura, S., Tamagawa, T., Fajiri, J. A., Li, F.: Effect of water circulation on the treated water quality of Johkasou-evaluation based on multivariate analysis-, J. Jpn. Soc. Civ. Eng., Ser. G (Environ. Res.), 72, III_255-III_265 (2016) (in Japanese)

18) Yasuda, M., Mihara, Y., Ohta, A., Nihei, M.: Influences of design factors on the denitrification in the circulated anoxicaerobic submerged bed process, J. Jpn. Soc. Water Environ., 17, 569-577 (1994) (in Japanese)

(Submitted 2017. 5. 18) (Accepted 2017. 9. 19) 